ACTA THERIOLOGICA

Vol. 31, 38: 523-535, 1986

\title{
Detoxification of Cadmium Ions by Metallothionein in the Liver of Free-living Bank Vole ${ }^{1}$
}

\author{
Tadeusz WŁOSTOWSKI
}

Włostowski T., 1986: Detoxification of cadmium ions by metallothionein in the liver of free-living bank vole. Acta theriol., 31, 38: 523-535 [With 4 Tables \& 2 Figs.]

Distribution of cadmium and zinc among cytosolic proteins of the liver and tissue respiration of this organ in bank vole, Clethrionomys glareolus (Schreber, 1780), living in the forest polluted with coal industry fumes and in the forest relatively slightly polluted were examined. Cadmium accumulated in the liver of the mature current year animals captured in September and of the overwintered animals captured in May in the polluted environment was bound with the metallothionein fraction $(60-70 \%)$ and with the high-molecular-weight cytosolic proteins $(20 \%)$. In the liver of the immature curient year animals captured in September, $100 \%$ of $\mathrm{Cd}$ ions were found in the form of complexes with metallothionein. Cd was not found in the liver of rodents captured in the forest of the small pollution. It has been stated that $\mathrm{Cd}$ ions bound with metallothionein in the liver of the current year voles living in the polluted forest are not reactjve and do not affect the tissue respiration of this organ. Though a remarkable part of the $\mathrm{Cd}$ ions is bound with metallothionein in the liver of the overwintered animals as well, yet the amount which is not bound with this protein (about $2 \mu \mathrm{g} / \mathrm{g}$ ) is high enough to change the level of the examined process. Cadmium accumulated in the voles liver does not change, however, the qualitative distribution of zinc among the cytosolic proteins of this organ. The obtained data indicate that except detoxification of cadmium by metallothionein, the short life span of voles causing the quick rate of replacement of the generations may play an important role in maintaining the biological continuity of the bank vole in polluted environment.

[Institute of Biology, University of Warsaw, Białystok Branch, Sosnowa $64,15-887$ Bialystok, Poland]

\section{INTRODUCTION}

Cadmium is a toxic element for animals and human beings (Friberg et al., 1974). The highest amounts of cadmium accumulate in liver and kidneys (Kotsonis \& Klaassen, 1978), where it simultaneously induces synthesis of metallothionein - a low-molecular-weight cytosolic protein

1 Praca wykonana w ramach problemu 10.2, koordynowanego przez Instytut Podstaw Inżynierii Srodowiska PAN. 
containing $30 \%$ of cysteinyl residues (Cherian \& Goyer, 1978). Though the physiological function of metallothionein is not completely elucidated, many authors suggest that the protein binding cadmium simultaneously detoxificates it (Nordberg et al., 1971; Webb, 1972; Leber \& Miya, 1976; Probst et al., 1977). The suggestion is also confirmed by Wiśniewska-Knypl \& Jabłońska (1970) who found out that the cadmium ions bound to metallothionein in the rat liver did not affect the activity of redox enzymes. Moreover, Laborit et al. (1980) showed that free ions of cadmium, non-bound to the protein, change the tissue respiration in these animals. Besides, it is postulated that metallothionein plays an important role in the metabolism of zinc and copper in mammals (Cousins, 1983).

The numerous studies dealing with the effect of cadmium on mammals metabolism have been up to date carried out mainly on laboratory animals which were administered high doses of this metal. No examinations have been reported, however, on free-living mammals in the environment polluted with cadmium i.e. exposed to the prolonged action of small amounts of this element. Coal and metallurgical industries covering remarkable area of the southern Poland are substantial source of the environment pollution with cadmium. It has been found that bank voles living in the forests of Rybnik Coal Region accumulate $0.5-6.0 \mu \mathrm{g} \mathrm{Cd} / \mathrm{g}$ wet liver, due to the time of habitation of rodents in the polluted environment (Włostowski, 1984). It is not known, however, whether the absorbed cadmium affects the animals metabolism.

In this paper an attempt has been undertaken to examine whether cadmium accumulated in the liver of bank vole, Clethrionomys glareolus (Schreber, 1780), living in a forest polluted with fumes from the coal industry can influence the tissue metabolism of this organ or whether the metal is detoxificated by metallothionein. For this reason a distribution of cadmium and zinc among cytosolic proteins and the tissue respiration of the liver was analyzed in voles living in the polluted and relatively pure environments.

\section{MATERIAL AND METHODS}

Bank vole males were captured by means of the live-traps in May and September 1982 in a forest polluted with emissions of the coal industry in the neighbourhood of Knurow in the Rybnik Coal Region. In this paper the area is named "Aniołki Forest". For the comparative purposes other voles were captured in Solnicki Forest near Bialystok which in this work is named „Białystok Forest”. Fall of dust on Aniołki Forest amounted to 450 tons $/ \mathrm{km}^{2} /$ year (Walkowa et al., 1982), and on Białystok Forest it was below 40 tons $/ \mathrm{km}^{2} /$ year (Włostowski, 1984). Cad- 
mium content in herbaceous plants from Aniołki Forest amounted to about $6 \mu \mathrm{g} / \mathrm{g}$ dry wt, whereas in the plants from Białystok Forest only traces of this metal were found (Włostowski, 1984).

The animals were captured in Aniolki and Białystok in the plant communities: Tilio-Carpinetum Tracz. 1962 and Pino-Quercetum (Kozł., 1925) Mat. et Pol. 1955. Animals captured in spring were born in the previous year and overwintered in the study area. The autumn group were rodents born in the spring-summer period of the same year (in this paper the animals are denoted ,current year animals”). In this group there were mature (born in spring) and immature animals (born in late spring and in summer).

Distribution of cadmium and zinc among proteins of the liver were examined in the overwintered voles from Aniołki Forest weighing $20-25 \mathrm{~g}$ and in the overwintered animals from Bialystok Forest weighing $20-23 \mathrm{~g}$. Current year animals captured in Aniolki Forest were divided into two groups: mature animals of the body weight $18-22 \mathrm{~g}$ and immature animals of the body weight $12-15 \mathrm{~g}$. Sexual maturity of the males was estimated according to the presence of spermatozoons in the testis. The current year rodents coming from Białystok Forest of the body weight $15-20 \mathrm{~g}$ were also examined.

After decapitation the livers were taken from 3-4 animals belonging to the above mentioned groups. $4 \mathrm{~g}$ of the wet liver were homogenized in $12 \mathrm{ml}$ of the $0.01 \mathrm{~m}$ Tris- $\mathrm{HCl}$ buffer $+0.25 \mathrm{~m}$ sucrose $(\mathrm{pH} 7.8)$ in Potter-Elvehjen homogenizer in the temperature of about $0^{\circ} \mathrm{C}$. A volume corresponding to $1 \mathrm{~g}$ of the liver was taken from the obtained homogenate to determine the total cadmium content. The remaining volume was centrifuged at $27000 \times \mathrm{g}$ for $10 \mathrm{~min}$ in the temperature of $4^{\circ} \mathrm{C}$. The supernatant was heated at $80^{\circ} \mathrm{C}$ for $2 \mathrm{~min}$ and centrifuged again at $27000 \times \mathrm{g}$ for $60 \mathrm{~min}$ (Cherian, 1974; Taguchi \& Nakamura, 1982). The final supernatant, in the volume corresponding to $1 \mathrm{~g}$ of the liver, was fractionated by column chromatography $(1.5 \times 60 \mathrm{~cm})$, using Sephadex G-75 fine (Pharmacia Fine Chemicals, Uppsala) equilibrated with $0.01 \mathrm{~m}$ Tris-HCl buffer, $\mathrm{pH}$ 7.8. The sample was eluted with the buffer solution described above at a flow rate of $10 \mathrm{ml} / \mathrm{h}$. The column void volume $\left(V_{o}\right)$ was estimated by use of the blue dextran and the eluate volume at which metallothionein (MT) is washed was determined by use of cytochrome C (mol. wt 12400). During the protein elution from the column their concentration in the fractions $(5 \mathrm{ml})$ was determined by ultraviolet absorption at $280 \mathrm{~nm}$. The concentrations of cadmium and zinc in the fractions were determined after digestion of the protein with nitric acid. Cadmium was estimated by a dithizone method (Saltzman, 1953), and zinc by atomic absorption spectrophoto- 
metry (AAS 1 Carl Zeiss Jena) with an air: acetylene flame. Cadmium was also analyzed in liver homogenates and supernatants after their previous digestion in the mixture of $\mathrm{HNO}_{3}$ and $\mathrm{HClO}_{4}(4: 1 \mathrm{v} / \mathrm{v})$. Separation of the liver cytosol on the Sephadex G-75 gel column was carried out twice for each group of animals.

Simultaneously the tissue respiration of the liver in bank voles was examined. Consumption of oxygen by the liver homogenates was estimated by a Warburg method (Pytasz et al., 1980). After arriving at the laboratory the animals were fasted for 24 hours with free access to water and then the rodents were killed by decapitation. Their livers were immediately removed and homogenized in Tyrode solution in the temperature of about $0^{\circ} \mathrm{C}$. In this way $20 \%$ liver homogenates were prepared. Consumption of oxygen by these homogenates was examined in the temperature of $37^{\circ} \mathrm{C}$ during 50 minutes. The obtained results are expressed in $\mu \mathrm{l} \mathrm{O}_{2} / \mathrm{g}$ wet $\mathrm{wt} / \mathrm{min}$.

An influence of free cadmium ions on the tissue respiration of the liver of the bank voles coming from the both environments was also determined. For this reason the livers were homogenized in Tyrode's fluid with the addition of cadmium in such amounts that its concentration in the homogenates corresponded to $1.0,2.0,5.0$ and $10.0 \mu \mathrm{g}$ $\mathrm{Cd} / \mathrm{g}$ wet liver. Cadmium was added in the form of cadmium chloride. The influence of the above mentioned concentrations on the tissue respiration was tested in the rodents captured in Białystok Forest in autumn. In the case of rodents from Aniołki Forest and overwintered animals from Białystok Forest only the effect of $5.0 \mu \mathrm{g} \mathrm{Cd} / \mathrm{g}$ was examined.

The results were statistically analyzed calculating the standard error of mean (SEM) and the differences between the mean values at $p<0.05$ using the Student $t$-test for the two independent groups.

\section{RESULTS}

\subsection{Distribution of Cadmium and Zinc among Proteins in the Bank Vole Liver}

Sephadex G-75 gel filtration of the liver cytosol showed that there are differences in the distribution of cadmium ions among cytosolic proteins of this organ in voles captured in spring and autumn in Aniołki Forest (Fig. 1). Cadmium ions were found in the fraction of high-molecular-weight proteins (peak I) and in the metallothionein fraction (peak III) in the livers of overwintered and mature current year voles (Fig. 1A, B). In the peak I there were about $20 \%$ and in the peak III $60-70 \%$ of the total cadmium accumulated in the liver. In immature 


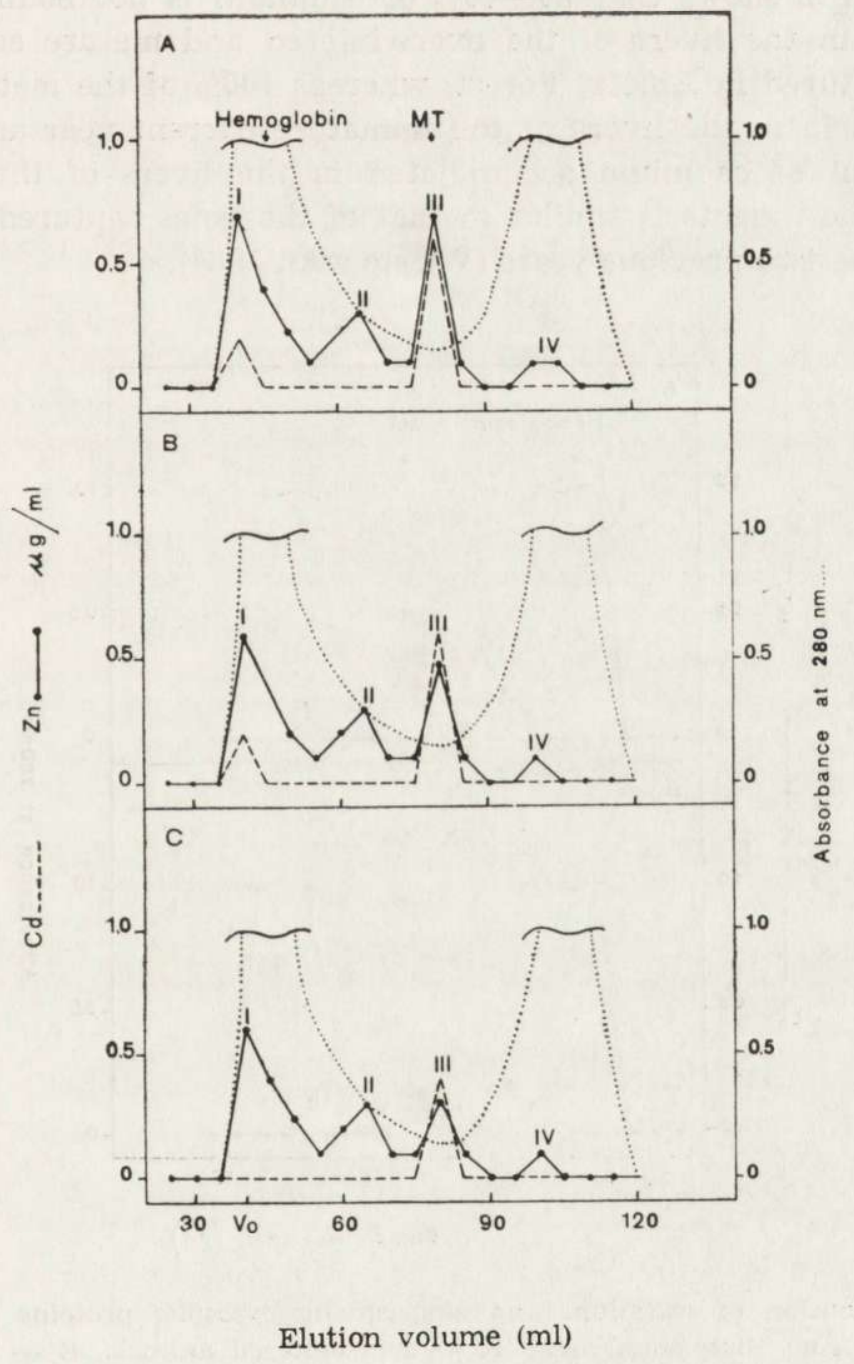

Fig. 1. Distribution of cadmium and zinc among cytosalic proteins in the liver of bank vole from Aniolki Forest. A - overwintered animals, B - mature current year animals, C - immature current year animals, MT - metallothionein.

current year rodents this metal was found only in the metallothionein fraction (Fig. 1C). No cadmium was noticed in the liver of bank voles both overwintered and current year animals coming from Białystok Forest (Fig. 2). 
The Table 1 shows that $30-40 \%$ of cadmium is not bound to metallothionein in the livers of the overwintered and mature current year rodents captured in Aniołki Forest, whereas $100 \%$ of the metal is bound to this protein in the livers of the immature current year animals. The total content of cadmium accumulated in the livers of the examined groups of the rodents is similar to that of the voles captured in Aniołki Forest in the two previous years (Włostowski, 1984).

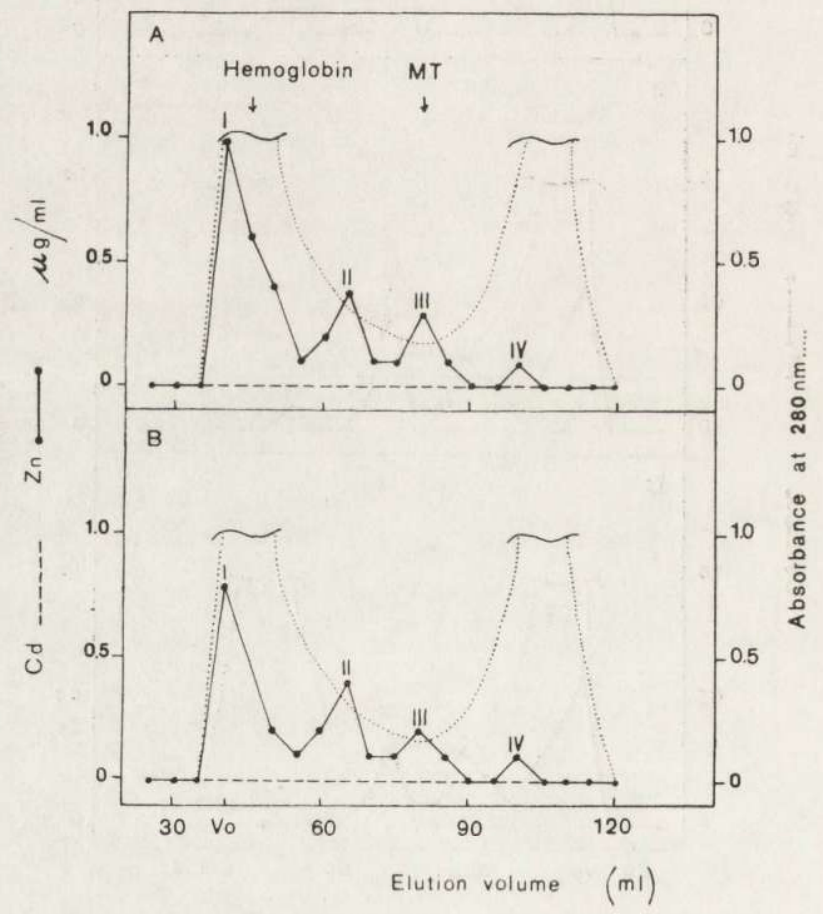

Fig. 2. Distribution of cadmium and zinc among cytosolic proteins in the liver of bank vole from Bialystok Forest. A - overwintered animals, B - current year animals, MT - metallothionein.

Table 1

Distribution of cadmium in the liver of bank vole captured in Aniolki Forest.

\begin{tabular}{|c|c|c|c|}
\hline Group of animals & $\begin{array}{l}\text { Amo } \\
\text { total }\end{array}$ & $\begin{array}{l}\text { of cadmium in } \mu \mathrm{g} / \\
\text { bound to } \\
\text { metallothionein }\end{array}$ & $\begin{array}{l}\text { /g wet liver } \\
\text { non-bound } \\
\text { to metallothionein }\end{array}$ \\
\hline Overwintered & 5.0 & 3.0 & 2.0 \\
\hline Mature, current year & 4.0 & 3.0 & 1.0 \\
\hline Immature, current year & 2.0 & 2.0 & - \\
\hline
\end{tabular}


Distribution of zinc among the liver cytosolic proteins was qualitatively similar in all groups of the animals (Fig. 1, 2). The highest amount of this element was found in the fraction of high-molecular-weight proteins (peak I). The amount of zinc in this peak in voles from Białystok Forest was higher than in animals from Aniołki Forest. The content of zinc in peak II was similar in all animals but in peak III the amount of this metal in the overwintered and mature current year animals living in Aniołki Forest was two times higher than in immature rodents coming from the same environment. About twofold higher content of zinc was also found in peak III in animals captured in Aniołki Forest in comparison with the voles captured in Bialystok Forest both in spring and autumn. The smallest amount of zinc was found in peak IV in all the voles where this metal is bound to low-molecular-weight substances or it occurs in the ion form.

\subsection{Influence of Cadmium on Tissue Respiration of the Bank Vole Liver}

The tissue respiration of liver in the current year voles both mature and immature coming from Aniołki and Białystok did not show significant differences and that is why the obtained results are jointly presented for the both groups (Table 2). Consumption of oxygen by the liver homogenates of the current year rodents from Aniołki Forest did

Table 2

Tissue respiration of the bank vole liver.

\begin{tabular}{lccc}
\hline Study area & Group of animals & $\begin{array}{c}\text { Number } \\
\text { of animals }\end{array}$ & $\mu \mathrm{l} \mathrm{O}_{2} / \mathrm{g} / \mathrm{min} \pm \mathrm{SEM}$ \\
\hline Aniołki Forest & Overwintered & 10 & $14.6 \pm 0.8^{1}$ \\
& Current year & 15 & $10.8 \pm 1.0$ \\
\hline Białystok Forest & Overwintered & 13 & $10.7 \pm 0.9$ \\
& Current year & 15 & $10.0 \pm 0.6$ \\
\hline
\end{tabular}

1 Statistically significant difference in comparison with the other groups of animals $p<0.05$ ).

not show significant differences in comparison with the analogous group of animals from Białystok Forest. But significantly higher level of tissue respiration was noticed in the overwintered animals from Aniołki Forest compared with the overwintered voles from Białystok Forest.

Free cadmium ions added into the liver homogenates of the current year animals from Białystok Forest (in the amounts of 2.0, 5.0 and $10.0 \mu \mathrm{g} / \mathrm{g}$ ) significantly stimulated the tissue respiration of this organ, but the intensity of the stimulation did not depend on the concentration 
of cadmium (Table 3). Intensity of the oxygen intake by these homogenates was similar to that of the overwintered animals living in Aniołki Forest (Table 2). Similarly, cadmium added (in the amount of $5.0 \mu \mathrm{g} / \mathrm{g}$ ) into the liver homogenates of the overwintered voles from Białystok

Table 3

Influence of different doses of cadmium on tissue respiration of the liver bank vole captured in Białystok Forest in autumn.

\begin{tabular}{ccc}
\hline $\begin{array}{l}\text { Amount of added cadmium } \\
\text { in } \mu \mathrm{g} / \mathrm{g} \text { wet liver }\end{array}$ & $\begin{array}{c}\text { Number } \\
\text { of animals }\end{array}$ & $\mu \mathrm{l} \mathrm{O}_{2} / \mathrm{g} / \mathrm{min} \pm \mathrm{SEM}$ \\
\hline Control & 15 & $10.0 \pm 0.6$ \\
1.0 & 8 & $10.8 \pm 0.5$ \\
2.0 & 9 & $13.8 \pm 0.4^{1}$ \\
5.0 & 6 & $14.2 \pm 0.7^{1}$ \\
10.0 & 5 & $14.5 \pm 0.6^{1}$
\end{tabular}

${ }^{1}$ Statistically significant difference in comparison with control $(p<0.05)$.

Forest did change the intensity of their respiration in comparison with the control group (Table 4). In the case of the overwintered animals from Aniołki Forest the added cadmium ions into the liver homogenates (in the amount of $5.0 \mu \mathrm{g} / \mathrm{g}$ ) did not change the intensity of the liver respiration compared with the control group (Table 4). But the added cadmium (in the amount of $5.0 \mu \mathrm{g} / \mathrm{g}$ ) distinctly stimulated the tissue

Table 4

Intensity of tissue respiration of the bank vole liver after administration of cadmium in vitro in the dose of $5.0 \mu \mathrm{g} / \mathrm{g}$ wet liver. C - control, $\mathrm{E}$ - experimental.

\begin{tabular}{lccccccccc}
\hline & \multicolumn{3}{c}{ Aniołki Forest } & \multicolumn{3}{c}{ Bialystok Forest } \\
\cline { 2 - 9 } Number & \multicolumn{3}{c}{ Overwintered } & \multicolumn{2}{c}{ Current } & year & \multicolumn{2}{c}{ Overwintered } & \multicolumn{2}{c}{ Current year } \\
& C & E & C & E & C & E & C & E \\
\hline of animals & 10 & 7 & 15 & 10 & 13 & 7 & 15 & 6 \\
$\mu 1 \mathrm{O}_{2} / \mathrm{g} / \mathrm{min}$ & 14.6 & 14.4 & 10.8 & 14.5 & 10.7 & 14.4 & 10.0 & 14.21 \\
$\pm \mathrm{SEM}$ & \pm 0.9 & \pm 0.9 & \pm 1.0 & \pm 0.7 & \pm 0.9 & \pm 0.7 & \pm 0.8 & \pm 0.7 \\
\hline
\end{tabular}

${ }^{1}$ Statistically significant difference in comparison with the control group $(p<0.05)$.

respiration in the current year animals from Aniołki Forest (Table 4). Intensity of the oxygen intake by the liver homogenates was in this case statistically equal to the level of the overwintered animals coming from the same environment (Table 2). 


\section{DISCUSSION}

Wiśniewska-Knypl \& Jabłońska (1970), Webb (1972), Yau \& Mennear (1977), Bakka \& Rugstad (1981), Taguchi \& Nakamura (1982) found that nearly $100 \%$ of cadmium ions concentrated in the cytosol of different animal tissues form complexes with metallothionein. Similar results were obtained in immature current year voles captured in September at Aniołki (Fig. 1C). A different distribution of cadmium among cytosolic proteins of the liver has been found in the overwintered and mature current year voles from the same environment (Fig. 1A, B). In this case cadmium has been stated in the liver not only in the form of complexes with metallothionein but also in the form of complexes with high-molecular-weight proteins. Similar distribution of cadmium among cytosolic proteins has been obtained in the liver of rats which have been administered high doses of this metal (Nordberg et al., 1971; Leber \& Miya, 1976). According to these authors the cadmium binding capacity of metallothionein becomes saturated when a high amount of cadmium is absorbed by the liver and that is why a part of $\mathrm{Cd}$ ions are bound to the other cytosolic proteins. Yet the amount of cadmium accumulated in the liver of the overwintered and mature current year voles is small and it seems likely that the metallothionein capacity is high enough to bind its total amount. It is evidenced by marked amount of zinc ions bound to this protein (Fig. 1) which are displaced by cadmium ions (Day et al., 1984). It should be supposed, therefore, that the failure of binding the total amount of cadmium by metallothionein in the liver of the animals from Aniołki Forest results from the other reasons. Perhaps the physiological condition of the rodents (sezual activity) and/or the time of the animals staying in the polluted environment play an important role here.

El-Gazzar et al. (1978) are of opinion that the toxicity of cadmium for animals may result, among others, from the fact that this metal changes the qualitative distribution of zinc ions among cytosolic proteins in the liver. The results of this study indicate, however, that cadmium accumulated in the liver of bank vole from Aniolki Forest has no negative effect on this process (Fig. 1,2). But cadmium evokes increase of the zinc level in the metallothionein fraction (peak III). It is shown by the fact that the amount of the zinc ions in this fraction increases with the increase of the cadmium content in the liver. And the observed smaller amounts of the zinc ions in the fraction of the high-molecular-weight proteins (peak I) in the bank vole from Aniołki Forest compared with the rodents from Białystok Forest, is probably connected with a smaller content of this element in the liver of animals from a polluted forest. It has been noticed, namely, that there were about 
$20 \mu \mathrm{g} \mathrm{Zn/g}$ in the voles from Aniołki Forest and $30 \mu \mathrm{g} \mathrm{Zn} / \mathrm{g}$ wet liver in the animals from Białystok Forest. This smaller concentration of zinc results from the marked increase of the liver biomass in the bank voles living in Aniołki Forest (Włostowski, 1984).

The present results show that the cadmium ions in the concentrations of $2.0,5.0$ and $10.0 \mu \mathrm{g} / \mathrm{g}$ wet liver significantly stimulate the tissue respiration of this organ (Table 3). Thus, the total content of cadmium accumulated in the liver of all rodent groups from the polluted forest as well as the amount of cadmium bound to the metallothionein fraction (Table 1) is so high that should change the intensity of an examined process. But this effect was not observed in the current year voles. It is evidenced by the similar levels of the liver respiration in the current year voles from Aniołki Forest and of the rodents living in the relatively pure forest (Table 2). These data indicate that cadmium bound to metallothionein in the liver of the voles from Aniołki Forest is not reactive. And the cadmium amount non-bound to this protein in the mature current year animals (about $1 \mu \mathrm{g} / \mathrm{g}$ ) is too small to change intensity of the tissue respiration (Table 3). The stimulation of this process was obtained only when additional free cadmium ions were administered into the liver homogenates of these animals (Table 4). Contrary to the current year animals, the amount of cadmium ions non-bound to metallothionein $(2 \mu \mathrm{g} / \mathrm{g})$ in the liver of the overwintered rodents from Aniołki Forest is high enough to stimulate the tissue respiration. Addition of the free cadmium ions into the liver homogenates did not change intensity of the process (Table 4). The above data indicate that metallothionein binding cadmium ions in the liver of voles living in Aniołki Forest simultaneously detoxificates it. Wiśniewska-Knypl \& Jabłońska (1970) also showed detoxification of cadmium ions by metallothionein in the liver of rats.

Examinations carried out up to now show that there are significant differences between bank voles born in the different periods of the breeding season, concerning among others, the rate of the sexual development, length of life and role in the population (Petrusewicz et al. 1969/70; Pucek et al., 1969/70; Fedyk, 1974) Majority of the animals born in late spring and during the summer and autumn do not participate in the reproduction in the current year. Individuals of these generations compose the overwintered group in the next year and just in this season they participate in the reproduction together with the early spring generation (Petrusewicz et al., 1969/70). This paper shows that the voles born in late spring and in summer (immature currrent year animals) accumulate small amounts of cadmium which is then completely bound and detoxificated by metallothionein (Table 1). 
Thanks to that this group of animals is not exposed to the negative effects of cadmium and may survive the winter in the physiological condition similar to that of the rodents living in the non-polluted environment. Though the physiological condition of these individuals after surviving the winter is deteriorated, which is shown by the liver tissue metabolism changed by cadmium, yet metallothionein binding considerable amounts of cadmium (Table 1) significantly reduces the concentration of free ions of this metal which could have a toxic effect on the animal metabolism. So the overwintered animals have the physiological condition good enough to reproduce and thus maintain the biological continuity of the population in the polluted environment. Similarly, the early spring individuals (mature current year animals) could participate in the reproduction because metallothionein binding most of cadmium accumulated in the liver enabled the animals to maintain fairly good physiological condition. This is evidenced by the litter size which is similar in the bank voles living both in Aniołki Forest and in environments of small pollution in other regions of Poland (Walkowa et al., 1982). So it seems that except detoxification of cadmium on the molecular level, the short life span of bank voles causing the quick rate of generations replacement plays an important role in maintaning the biological continuity of the rodent population in the polluted environment.

Acknowledgements: I wish to thank Ass. Prof. A. Kostelecka-Myrcha for her most valuable help and critical remarks during writing this paper. I am also grateful to Prof. A. Kubicz, Prof. K. Dobrowolski and Ass. Prof. A. Górecki for their valuable remarks.

\section{REFERENCES}

1. Bakka A. \& Rugstad H. E., 1981: Uptake and agress of cadmium in cultures of cadmium-resistant and the corresponding "wild-type" cells. Acta pharmacol. toxicol., 48: $81-86$.

2. Cherian M. G., 1974: Isolation and purification of cadmium binding proteins from rat liver. Biochem. Biophys. Res. Commun., 61: 923-926.

3. Cherian M. G. \& Goyer R. A., 1978: Metallothioneins and their role in the metabolism and toxicity of metals. Life Sci., 23: 1-10.

4. Cousins R. J., 1983: Metallothionein - aspects related to copper and zinc metabolism. J. Inher. Metab. Dis. 6 Suppl. 1: 15-21.

5. Day F. A., Funk A. E. \& Brady F. O., 1984: In vivo and ex vivo displacement of zinc from metallothionein by cadmium and by mercury. Chem. Biol. Interact., 50: $159-174$

6. El-Gazzar R., Boyle J., Cornicelli J. \& Petering H. G., 1978: Effect of cadmium ingestion on cadmium and zinc profile in male and female rat liver cytosol Biochem. Pharmacol., 27: 2001-2008.

7. Fedyk A., 1974: Gross body composition in postnatal development of the bank vole. II. Deferentiation of seasonal generations. Acta theriol., 19: 403-427. 
8. Friberg L., Piscator M., Nordberg G. F. \& Kjellstrom T., 1974: Cadmium in the Environment. CRC Press: 1-247. Cleveland, Ohio.

9. Kotsonis F. N. \& Klaassen C. D., 1978: The relationship of metallothionein to the toxicity of cadmium after prolonged oral administration to rats. Toxicol. appl. Pharmacol., 46: 39-54.

10. Laborit H., Baron C., Ferran C., Bonifay J. F., Topall G. \& Henriet I., 1980: Variations de la toxicite du cadmium en rapport avec les possibilities de controle des situations environmentales per l'activite motrice chez le rat. Agressologie, 21: 269-290.

11. Leber A. P. \& Miya T., 1976: A mechanism for cadmium and zinc-induced tolerance to cadmium toxicity. Involvement of metallothionein. Toxicol. appl. Pharmacol., 37: 403-414.

12. Nordberg G. F., Piscator M. \& Lind B., 1971: Distribution of cadmium among protein fractions of mouse liver. Acta pharmacol. toxicol., 29: 456-470.

13. Petrusewicz K., Andrzejewski R., Bujalska G. \& Gliwicz J., 1969/70: The role of spring, summer and autumn generations in the productivity of a free-living population of Clethrionomys glareolus. [In: "Energy flow through small mammal populations", Eds. K. Petrusewicz \& L. Ryszkowski] PWN: 235-245, Warsaw.

14. Probst G., Bousquet W. \& Miya T., 1977: Correlation of hepatic metallothionein concentrations with acute cadmium toxicity in the mouse. Toxicol. appl. Pharmacol., 39: $61-67$.

15. Pucek Z., Ryszkowski L. \& Zejda J., 1969/70: Estimation of average length of life in bank vole, Clethrionomys glareolus (Schreber, 1780). [In: "Energy flow through small mammal populations", Eds. K. Petrusewicz \& L. Ryszkowski] PWN: 187-201, Warsaw.

16. Pytasz M., Zawadzka A., Doleżych B. \& Szmatloch A., 1980: The tissue respiration in selected homeothermic species from the ironwork "Katowice" region. Acta biol. (Katowice), 8: 115-123.

17. Saltzman B. E., 1953: Colorimetric microdetermination of cadmium with dithizone. 'With improved separation of interfering metals. Anal. Chem., 25: 493-497.

18. Taguchi T. \& Nakamura K., 1982: Isolation and properties of cadmium-binding protein induced in rat small intestine by oral administration of cadmium. J. Toxicol. environ. Health, 9: 401-409.

19. Walkowa W., Adamczyk K. \& Chelkowska H., 1982: Numbers and structure of rodent communities in the forest environment of Silesia. Pol. ecol. Stud., 8: $305-330$.

20. Webb M., 1972: Binding of cadmium ions by rat liver and kidney. Biochem. Pharmacol., 21: $2751-2765$.

21. Wiśniewska-Knypl J. M. \& Jabłońska J., 1970: Selective binding of cadmium in vivo on metallothionein in rats liver. Bull. Acad. Pol. Sci. Ser. Biol., 18: $321-327$.

22. Włostowski T., 1984: Mechanizmy zabezpieczające dziko żyjące gryzonie przed oddziaływaniem metali ciężkich zawartych w pyłach emitowanych przez przemysł węglowy. Ph. D. Thesis, Warsaw Univ., $1-59$, Białystok.

23. Yau E. T. \& Mennear J. H., 1977: Pancreatic metallothionein: protection against cadmium-induced inhibition of insulin secretory activity. Toxicol. appl. Pharmacol., 39: 515-520.

Accepted, March 5, 1986. 
Tadeusz WŁOSTOWSKI

INAKTYWACJA JONOW KADMU PRZEZ METALOTIONEINE W WĄTROBIE
DZIKO ŻYJĄCEJ NORNICY RUDEJ

Streszczenie

Zbadano rozmieszczenie kadmu i cynku wśród białek cytoplazmatycznych wątroby oraz oddychanie tkankowe tego narządu $u$ nornicy rudej, Clethrionomys glareolus (Schreber, 1780), żyjącej w lesie zanieczyszczonym emisjami przemysłu węglowego (Rybnicki Okręg Węglowy) i w lesie stosunkowo malo zanieczyszczonym (Białystok). U dojrzalych płciowo zwierząt tegorocznych odłowionych we wrześniu i u przezimków odłowionych $w$ maju $w$ zanieczyszczonym środowisku, zakumulowany $\mathrm{w}$ wątrobie kadm związany jest $\mathrm{z}$ frakcją metalotioneiny $(60--70 \%$ ) i z frakcją cytoplazmatycznych białek wielkocząsteczkowych $(20 \%)$, natomiast w wątrobie niedojrzalych płciowo zwierząt tegorocznych odłowionych we wrześniu, $100 \%$ jonów kadmu występuje $\mathrm{w}$ formie kompleksu $\mathrm{z}$ metalotioneiną (Ryc. 1, Tabela 1). W wątrobie gryzoni $\mathrm{z}$ lasu mało zanieczyszczonego nie stwierdzono kadmu (Ryc. 2).

Stwierdzono, że wolne jony kadmu, wniesione do homogenatów wątroby nornic pochodzących ze środowiska stosunkowo czystego, w ilości $2.0,5.0$ i $10.0 \mu \mathrm{g} / \mathrm{g}$ istotnie stymulują oddychanie tkankowe tego narządu, przy czym poziom tej stymulacji nie zależy od stężenia kadmu (Tabela 3). Ogólna ilość kadmu nagromadzonego w wątrobie wszystkich grup gryzoni $\mathrm{z}$ lasu zanieczyszczonego emisjami przemysłu węglowego, jak również jego ilość połączona $\mathrm{z}$ frakcją metalotioneiny (Tabela 1) jest wystarczająco duża, aby zmienić intensywność tego procesu. Nie stwierdzono jednak takiego efektu $u$ nornic tegorocznych, o czym świadczy podobny poziom oddychania wątroby tych zwierząt i wątroby gryzoni z lasu mało zanieczyszczonego (Tabela 2). Dane te wskazują, że kadm związany $z$ frakcją metalotioneiny $\mathrm{w}$ wątrobie tych nornic $\mathrm{z}$ lasu zanieczyszczonego jest nieaktywny. Jego ilošć nie związana $\mathrm{z}$ tym białkiem $\mathrm{u}$ dojrzałych płciowo osobników tegorocznych (około $1 \mu \mathrm{g} / \mathrm{g}$ ) (Tabela 1 ) jest natomiast za mała, aby zmienić intensywność oddychania tkankowego (Tabela 3). Dopiero wniesienie dodatkowej ilości wolnych jonów kadmu do homogenatów wątroby tych zwierząt spowodowało stymulację tego procesu (Tabela 4). W przeciwieństwie do gryzoni tegorocznych, w wątrobie przezimków z lasu zanieczyszczonego emisjami przemysłu węglowego, ilość jonów kadmu nie związanych $\mathrm{z}$ frakcją metalotioneiny (około $2 \mu \mathrm{g} / \mathrm{g}$ ) (Tabela 1) jest na tyle duża, że stymuluje oddychanie tkankowe (Tabela 2). Wniesienie dodatkowej ilości wolnych jonów kadmu do homogenatów ich wątroby nie zmieniło już intensywności tego procesu (Tabela 4).

Kadm nagromadzony $w$ wątrobie nornicy rudej nie zmienia jakościowego rozmieszczenia cynku wśród białek cytoplazmatycznych tego narządu. Wykazano natomiast, że wraz ze wzrostem ilości kadmu w wątrobie wzrasta ilość jonów cynku połączonych $\mathrm{z}$ frakcją metalotioneiny (Ryc. 1).

$\mathrm{Z}$ uzyskanych danych wynika, że obok inaktywacji kadmu przez metalotioneinę, ważną rolę w utrzymaniu ciągłości populacji nornicy rudej w zanieczyszczonym środowisku odgrywa także krótki okres życia nornic, prowadzący do szybkiego tempa wymiany pokoleń. 